\title{
A Study of English Phonological Errors Produced by English Department Students
}

\author{
Nani Indrajani Tiono, Arlene Maria Yostanto \\ English Department, Faculty of Letters, Petra Christian University, \\ Siwalankerto 121-131, Surabaya, East Java, Indonesia \\ e-mail: nitiono@peter.petra.ac.id; blue_amy84@yahoo.com
}

\begin{abstract}
This qualitative research was conducted to find out the kinds of English phonological errors produced by English department students, particularly English consonantal sounds that do not exist in

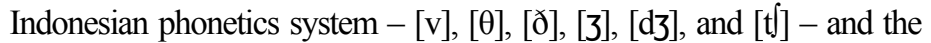
patterns of those errors. The result shows that the students produced thirty-four kinds of phonological errors and that the deviations occurred most frequently before, after, or in between vowels.
\end{abstract}

Key words: errors, phonological errors

According to Brown (2005) as cited in Lanteigne (2006, p. 3), the goal of the language learners is to make sure that they can communicate what they have in mind effectively; they have to be understood when they are uttering the words. Knowing that precision in pronouncing words is especially essential, language learners should pay more attention on the way they articulate the foreign words and, most importantly, master pronunciation of a language they are learning.

Odden (2006) relates pronunciation to the foundation areas of linguistics that deal with scientific study of the language structure, that is, phonology (p. 2). Furthermore, he mentions that different from other linguistics fields, language structure discussed in phonology is closely related to the study of sound structure in a language. Subsequently, in essence, phonology deals with two main things, phonemics, that is, the study of the distinctive sound units, and phonetics that mainly deals with speech sounds (Richards, Platt, \& Weber, 1992, p. 215). It should be noticed that to the same extent as phonology, pronunciation, basically, also deals with sounds. The difference is that pronunciation does not concern with the phonemics, but it focuses mainly on phonetics as Brown (1992) explains that what language learners must understand about pronunciation 
is that essentially 'any attention to pronunciation is phonetics' (as cited in Bowman, 2002, p. 1).

In the area of pronunciation, English language can be categorized as a difficult language to master. This statement is strengthened by Vernick and Nesgoda (1980) who state that language learners may find difficulties in learning to speak English well because several spelling may be represented by a single sound (p. xi). Different from Vernick and Nesgoda's opinion, Lanteigne (2006) confirms that difficulties in learning English occur due to the fact that some of English sounds do not exist in the mother tongue of the learners (p. 1). Dreasher and Anderson-Hsieh (1990) affirm Lanteigne's idea by stating that the sound [ $\theta],[ð],[\eta]$ and, [æ] of English sounds, for instance, do not exist in Portuguese (as cited in Lanteigne, 2006, p.1). Another example can be seen in Indonesian language; English

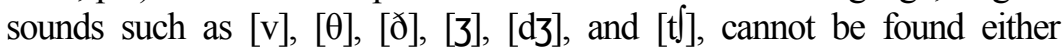
(Moeliono \& Dardjowidjojo, 2003, p. 55). Furthermore, the way of pronouncing one particular sound may be different based on "the position of the sound in the word" (Prator \& Robinett, 1972, pp. 86-88). As an illustration, $[\mathrm{t}]$ in 'taking' [ $\mathrm{t}$ eykIn] and in 'atom' [ǽtəm] is pronounced in a different way. It should be noted that when [t] is positioned in the initial position, it is aspirated. However, if it is put in the medial position, it is no longer aspirated. This fact also contributes to the difficulties in learning English. As a consequence of all the difficulties provided by the English pronunciation, many English language learners as well as the Indonesian learners tend to generate errors in the articulation of the sounds. Therefore, this research was done to observe the phonological errors done by the Indonesian English learners in order to find out firstly the kinds of phonological errors made by the students in producing the English consonantal sounds which do not exist in Indonesian sound system -

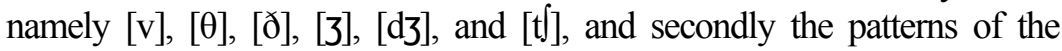
phonological deviations.

\section{METHODOLOGY}

This research was conducted by using the qualitative approach in which the source of data was from the phonetic transcription of the recorded pronunciation of twenty-five English department students who studied in a private university in Surabaya, a city in East Java, Indonesia. The subjects had taken speaking class for six semesters. Furthermore, since the data needed related only to the English consonantal sounds that do not exist in Indonesian, the phonetic transcription of the students' 
pronunciation was restricted only to the transcription of the words which contained the six English consonantal sounds. A tape recorder and pronunciation tasks, which were composed from the pronunciation exercises taken from Pronunciation in Action (Taylor, 1993), Pronunciation Exercises in English (Clarey \& Dixson, 1963) and The Sounds of English (Deterding \& Poedjosoedarmo, 1998), and from the ESL website (http://international.ouc.bc.ca/pronunciation/), were used to collect the data.

Having the phonetic transcription of the data which was done manually, the analysis began with the identification of the errors by comparing each student's actual pronunciation with the standard phonetic transcription. Then, those deviations found were listed down based on each sound and each position of occurrences in a table, as seen in Table 1. The table also included the phonological environment where the deviations occurred to explain about the circumstances in which the deviations occurred.

After listing down the deviations, the deviations were explained from the standpoint of English phonetic systems based on O'Grady, W., Dobrovolsky, M., \& Katamba, F. (1996). Afterwards, detailed descriptions to each of the deviations were noted down by relating the deviations to the Indonesian consonantal sounds based on the theory from Dardjowidjojo \& Moeliono (2003, pp. 65-77). Then, in order to have further explanation about the errors, the linguistic environments when the deviations occurred were also described by using the symbols from Fasold and ConnorLinton's (2006, pp. 47-48) theory of Phonological Rules.

\section{FINDINGS AND DISCUSSION}

The findings were grouped based on the six consonantal sounds investigated in this study, they are $[\mathrm{v}],[\theta],[ð],[3],[\mathrm{d} 3]$, and $[\mathrm{t}]$ ]. For additional description, each of those sounds was then classified into three categories in relation to the positions of their occurrences: they are initial, medial and final positions. Moreover, the phonological environments of the deviations were also formulated with the intention that further explanation about the patterns of the deviations could be provided.

\section{The Pronunciation of [v]}

The English sound [v] is described as a voiced labiodental fricative, which means that a speaker produces this kind of sound only if he or she fulfils those three main features of $[\mathrm{v}]$ sound. Nonetheless, this particular 
sound cannot be found in Indonesian phonetic system. Table 1 shows that the subjects tended to make errors in pronouncing [v] in all of the three positions, but they made merely one kind of deviation, that is, [v] was replaced with [f] since the sound [f] shares the same place and manner of articulation: labiodental fricative sounds. The distinction is only on the state of the vocal cords: $[\mathrm{v}]$ is a voiced sound while [f] is a voiceless sound.

Table 1. The Deviation of [v]

\begin{tabular}{|c|c|c|c|c|c|c|}
\hline $\begin{array}{l}\text { Positi- } \\
\text { ons }\end{array}$ & Words & $\begin{array}{c}\text { Standard } \\
\text { Phonetics } \\
\text { Transcripti } \\
\text { on }\end{array}$ & $\begin{array}{c}\text { Students' } \\
\text { Actual } \\
\text { Pronuncia- } \\
\text { tion }\end{array}$ & Deviations & $\begin{array}{l}\text { Phonological } \\
\text { Environments }\end{array}$ & $\begin{array}{c}\% \text { of } \\
\text { Errors }\end{array}$ \\
\hline \multirow{3}{*}{ initial } & villa & [vIlə] & [frla] & \multirow{3}{*}[\mathrm{v}\rightarrow\mathrm{f}]{} & $v \rightarrow f / \# \_V$ & $100 \%$ \\
\hline & viper & [vaIpər] & [faIpər] & & $v \rightarrow f / \# \_V v$ & $88 \%$ \\
\hline & very & [veri] & [feri] & & $\mathrm{v} \rightarrow \mathrm{f} / \# \mathrm{~V}$ & $84 \%$ \\
\hline \multirow{3}{*}{ medial } & drivels & [drIvlz] & [draIflz] & \multirow{3}{*}[v\rightarrowf]{} & $\mathrm{v} \rightarrow \mathrm{f} / \# \mathrm{CCV} v_{-} \mathrm{CC} \#$ & $88 \%$ \\
\hline & clever & [klevər] & [klefər] & & $\mathrm{v} \rightarrow \mathrm{f} / \mathrm{HCCV}$ _VC\# & $88 \%$ \\
\hline & groves & [grouvz] & [grufz] & & $\mathrm{v} \rightarrow \mathrm{f} / \# \mathrm{CCV} \_\mathrm{C} \#$ & $88 \%$ \\
\hline \multirow{3}{*}{ final } & serve & {$[\mathrm{s} 3: \mathrm{Iv}]$} & {$[\mathrm{s} 3: \mathrm{f}]$} & \multirow{3}{*}[\mathrm{v}\rightarrow\mathrm{f}]{} & \multirow{3}{*}{$\mathrm{v} \rightarrow \mathrm{f} / \# \mathrm{CV}_{-} \#$} & $100 \%$ \\
\hline & give & [gIv] & [gIf] & & & $96 \%$ \\
\hline & jive & [dzaIv] & [dzif] & & & $96 \%$ \\
\hline
\end{tabular}

Notes of the phonetic symbols used in Tables 1-6:

[...] : symbol of pronunciation

$\rightarrow \quad$ : showing a sound is pronounced as another sound

$\#$ \#.. : showing initial position

...\# : showing final position

: the deviated pronounced consonant

T : showing that the patterns occur in the following circumstances

$\{\ldots\}$ : showing choices

C : a consonant

$\mathrm{CC}$ : two consonants cluster

$\mathrm{V}$ : a vowel

Vv : a diphthong

As seen in Table 1, the process of the deviation of the sound [v] into the sound [f] in the initial position could be formulated as:

$$
\mathrm{v} \rightarrow \mathrm{f} /\left\{\begin{array}{c}
\#-\mathrm{V} \\
\# \_\mathrm{Vv}
\end{array}\right\}
$$


The formula above means that the phonological environment composed represents two possibilities. The first possibility is that [f] replaced $[\mathrm{v}]$ in the initial position before a vowel, for example in the students' pronunciation of the words 'villa' as [ftla] and 'very' as [feri]. The second one occurred in the initial position before a diphthong, such as 'viper' [faIpər].

The deviation of the sound $[\mathrm{v}]$ into the sound [f] in the medial position had three different phonological environments:

$$
\mathrm{v} \rightarrow \mathrm{f} /\left\{\begin{array}{c}
\# \mathrm{CCV} v_{-} \mathrm{CC} \# \\
\# \mathrm{CCV} \_\mathrm{VC} \# \\
\# \mathrm{CCV} \_\mathrm{CH}
\end{array}\right\}
$$

It happened in the medial position after a diphthong and before a consonant cluster, such as in 'drivels' [draIflz], between two vowels, for instance, 'clever' [klefər], and between a vowel and a consonant, for instance, groves [groufz].

The deviation of $[\mathrm{v}]$ into $[\mathrm{f}]$ in the final position only had one phonological environment, that is, after a vowel

$$
\mathrm{v} \rightarrow \mathrm{f} / \# \mathrm{CV}_{-} \#
$$

as in the pronunciation of 'serve' [s3:f], 'give' [gIf], and 'jive' [dzif].

In Table 1 , it can be seen that more than eighty percents of all the students made this particular deviation (i.e. the replacement of [v] with [f]) in each of the three positions of the occurrences. The reason behind this substitution of the sound [v] for [f] might occur mainly due to the fact that Indonesian phonetic system does not have voiced sound in its labiodental fricative. Hence, most of them replaced [v] with [f] and made it to be the only pattern of error.

\section{The Pronunciation of $[ð]$}

$[ð]$ is another original English consonantal sound that does not exist in Indonesian phonetic system. In English, it is listed as voiced dental fricative. Despite its clear-cut definition of how this sound should be produced, many English learners as the subjects of this research still produced errors when they had to articulate [ð] correctly as seen in Table 2. 
Table 2. The Deviation of [ $[0]$

\begin{tabular}{|c|c|c|c|c|c|c|}
\hline $\begin{array}{l}\text { Positi- } \\
\text { ons }\end{array}$ & Words & $\begin{array}{c}\text { Standard } \\
\text { Phonetics } \\
\text { Transcriptio } \\
\text { n }\end{array}$ & $\begin{array}{l}\text { Students' } \\
\text { Actual } \\
\text { Pronunci- } \\
\text { ation }\end{array}$ & $\begin{array}{l}\text { Deviati- } \\
\text { ons }\end{array}$ & $\begin{array}{l}\text { Phonological } \\
\text { Environments }\end{array}$ & $\begin{array}{l}\% \text { of } \\
\text { Errors }\end{array}$ \\
\hline \multirow{6}{*}{ initial } & they & [ðеI] & {$[\mathrm{deI}]$} & \multirow[b]{2}{*}[ð\rightarrowd]{} & ð $\rightarrow \mathrm{d} / \#$ _Vv\# & $100 \%$ \\
\hline & $\begin{array}{l}\text { there } \\
\text { then }\end{array}$ & $\begin{array}{l}\text { [ð॰] } \\
\text { [ðеn] }\end{array}$ & $\begin{array}{l}\text { [dər] } \\
\text { [den] }\end{array}$ & & ə $\rightarrow \mathrm{d} / \#$ \#_VC\# & $\begin{array}{l}80 \% \\
76 \%\end{array}$ \\
\hline & thou & [ðаひ] & [tov] & \multirow{2}{*}[\partial\rightarrowt]{} & ð $\rightarrow \mathrm{t} / \#$ _Vv\# & $8 \%$ \\
\hline & them & [ðəm] & [təm] & & ə $\rightarrow \mathrm{t} / \#$ _VC\# & $4 \%$ \\
\hline & though & [ðоひ $]$ & {$[\theta \mathrm{ou}]$} & \multirow{2}{*}[ð\rightarrow\theta]{} & ১ $\rightarrow \theta / \#$ _Vv\# & $12 \%$ \\
\hline & there & [ð॰r] & {$[\theta ə r]$} & & ə $\rightarrow \theta / \#$ /VC\# & $4 \%$ \\
\hline \multirow{9}{*}{ medial } & bother & [ba:ðər] & [ba:dər] & \multirow{3}{*}[\partial\rightarrowd]{} & \multirow{2}{*}{ ð $\rightarrow \mathrm{d} / \mathrm{V}_{-} \mathrm{V}$} & $80 \%$ \\
\hline & other & [^ðər] & {$[\wedge \mathrm{d} r]$} & & & $76 \%$ \\
\hline & although & [b:lðou] & [b:ldou] & & ð $\rightarrow \mathrm{d} / \# \mathrm{VC}_{\text {_ }} \mathrm{Vv} \#$ & $76 \%$ \\
\hline & soothing & [su:ðIy] & [su:tIn] & & & $84 \%$ \\
\hline & worthy & [W3:ðI] & [w3:tI] & {$[ð \rightarrow t]$} & ə $\rightarrow \mathrm{t} / \mathrm{V}_{-} \mathrm{V}$ & $64 \%$ \\
\hline & writhing & [raIðIy] & [rItIy] & & & $52 \%$ \\
\hline & writhing & [ratðIy] & [ri $\theta \mathrm{I} \eta]$ & & $ð \rightarrow \theta / \mathrm{V} \quad \mathrm{V}$ & $28 \%$ \\
\hline & worthy & [W3:ðI] & {$[\mathrm{w} 3: \theta \mathrm{I}]$} & {$[ð \rightarrow \theta]$} & & $28 \%$ \\
\hline & northern & [nכ:rðørn] & [nכ:rrசərn] & & ə $\rightarrow \theta / \# \mathrm{CVC}_{2} \mathrm{VCC} \#$ & $12 \%$ \\
\hline \multirow{7}{*}{ final } & seethe & {$[\operatorname{siz} ð]$} & [sirt] & \multirow{3}{*}[\partial\rightarrow\mathrm{t}]{} & \multirow{3}{*}{ ð $\rightarrow \mathrm{t} / \mathrm{CV}_{-} \#$} & $96 \%$ \\
\hline & sheathe & [ & {$\left[\int \mathrm{irt} t\right]$} & & & $92 \%$ \\
\hline & breathe & [briyd] & [brixt] & & & $92 \%$ \\
\hline & soothe & [surd] & {$[\operatorname{sur} \theta]$} & \multirow{3}{*}[ð\rightarrow\theta]{} & \multirow{3}{*}{ ð $\rightarrow \theta / \# \mathrm{CV}_{-} \#$} & $20 \%$ \\
\hline & with & [wIð] & {$[\mathrm{wI} \theta]$} & & & $20 \%$ \\
\hline & bathe & [beIð] & [b3 $\theta]$ & & & $16 \%$ \\
\hline & loathe & [loひð] & {$\left[\mathrm{lot}^{\mathrm{h}}\right]$} & {$\left[ð \rightarrow t^{h}\right]$} & ठ $\rightarrow \mathrm{t}^{\mathrm{h}} / \# \mathrm{CV} \_\#$ & $4 \%$ \\
\hline
\end{tabular}

Notably, there were four deviations made by the students in articulating [ð]. They were the replacement of [ð] with [d], the substitution of [ð] with [t], the switching of [ð] to $[\theta]$, and the changing of [ð] with $\left[\mathrm{t}^{\mathrm{h}}\right]$. Some of these deviations could be found in all of the three positions and some could only be noticed in either one or two positions. 


\section{- [ð] pronounced as [d]}

The replacement of [ð] with [d], in articulating [ð] signified that [ð] as a voiced dental fricative was being replaced with [d] which is a voiced alveolar stop. In this deviation, the students fulfilled one feature of the $[\delta]$ sound since $[ð]$ and $[\mathrm{d}]$ share the one identical characteristic, that is, voiced. However, when they articulated [d], the two other important elements of [ð] sound were deviated. The divergence could be observed because of the different place and manner of articulation of the two sounds. Normally, to make the sound [ð], the tip of the tongue is put behind the upper front teeth. However, in this case, the students put the front part of their tongue on their alveolar ridge, causing the alveolar sound to be produced rather than dental sound. In terms of manner of articulation, [ð] should be produced with the almost blocked air stream being pushed through the narrow opening and as a result creating 'hissing noise'. Yet, the students completely stopped the air stream and then released it abruptly resulting on a very different manner of articulation, that is, stop. Consequently, the students made deviation by replacing [ð] with [d].

In initial position, the substitution of [ð] with [d] had the phonological environment pattern as seen in Table 2:

$$
\text { ठ } \rightarrow \mathrm{d} /\left\{\begin{array}{l}
\# \_\mathrm{Vv} \# \\
\# \_\mathrm{VC} \#
\end{array}\right\}
$$

It happened before a diphthong, such as in 'they' [deI], and before a vowel, namely in 'there' [der] and 'then' [den]. In medial position of a word, the deviation had two possibilities:

$$
\text { ठ } \rightarrow \mathrm{d} /\left\{\begin{array}{c}
\mathrm{V}-\mathrm{V} \\
\# \mathrm{VC}_{-} \mathrm{Vv}
\end{array}\right\}
$$

First, when [ð] was between two vowels as in 'bother' [ba:dər] and when [ð] was between a consonant and a diphthong, for instance, in the word 'although' [b:ldou]. The substitution of the sound [ð] with [d] did not happen in the final position.

\section{- [ð] pronounced as $[\mathbf{t}]$}

The second deviation found in the pronunciation of [ð] was the substitution of [ð] with [t], as in 'thou' [tou], 'worthy' [w3:tt] and 'sheathe' [ $\mathrm{i}$ iðd]. In this deviation, the students completely altered all of the 
elements of [ð]. Firstly, in terms of state of the vocal cords, they did not vibrate their vocal cords as they should. Secondly, they constructed alveolar sound in place of dental. Finally, for the manner of articulation, they were more likely to produce a stop sound rather than a fricative sound. As a result, they produced a very distinct sound from [ð], that is, [t].

In initial position, the deviation could be formulated as:

$$
\partial \rightarrow \mathrm{t} /\left\{\begin{array}{l}
\# \_ \text {Vv\# } \\
\# \_ \text {_VC\# }
\end{array}\right\}
$$

The pattern states that the deviation of $[ð]$ to $[t]$ happened in the initial position before a diphthong and before a vowel, for instance, in 'thou' [tou] and 'them' [tom]. In medial position, the deviation could be formulated as:

$$
\partial \rightarrow \mathrm{t} / \mathrm{V}_{-} \mathrm{V}
$$

which shows that [ð] was replaced by $[t]$ if $[\delta]$ was placed in the medial position in between two vowels, for example, in the word 'soothing' [su:tIy] or 'worthy' [w3:tr]. In final position, the deviation was formulated as:

$$
\text { ð } \rightarrow \mathrm{t} / \mathrm{CV}_{-} \#
$$

The linguistic environment of the deviation in the final position of a word after a vowel, as in 'seethe' [sirt], 'sheathe' [Sirt], and 'breathe' [brist].

\section{- $[\boldsymbol{\delta}]$ pronounced as $[\theta]$}

Another deviation of $[\varnothing]$ happened when the students articulated $[\theta]$ for the sound [ð] such as in the pronunciation of 'there' [Oer], 'writhing' [rI $\mathrm{IIy}]$ and 'soothe' [su: $\theta]$. Essentially, when producing this deviation, the students made the least alteration of all four deviations of [ð] since they still managed to produce the sound properly in the area of place and manner of articulation - they were able to produce dental fricative sound. In this identifiable deviation, they only deviated the state of the vocal cords since they did not vibrate their vocal cords in producing the [ð] sound, resulting on the occurrence of the nearest sound that had the equivalent result, that is, $[\theta]$. 
In initial position, the deviation happened before a diphthong, as in the word 'though' $[\theta 0 \mho]$, and before a vowel, particularly in the word 'there' $[\theta \mathrm{er}]$. It could be formulated as:

$$
\text { ๖ } \theta \text { / }\left\{\begin{array}{l}
\# \_\mathrm{Vv} \# \\
\# \_\mathrm{VC} \#
\end{array}\right\}
$$

In medial position, the deviation became:

$$
\partial \rightarrow \theta /\left\{\begin{array}{c}
\mathrm{V}_{-}-\mathrm{V} \\
\# \mathrm{CVC}_{-} \mathrm{VCC} \#
\end{array}\right\}
$$

This pattern contains two possibilities. First, the substitution of [ð] to [ $\theta]$ happened in the medial position between two vowels, such as in 'writhing' [ri $\theta \mathrm{II}]$ and 'worthy' [w3: $\theta \mathrm{I}]$. Then, it happened in the medial position between a consonant and a vowel, for example, in the word 'northern' [nכ:rӨorn].

In final position, [ð] was pronounced as $[\theta]$ after a vowel such as in 'soothe' [sur $\theta]$, 'with' [wI $\theta]$, and 'bathe' [b3 $\theta$ ] with the description as:.

$$
\text { ๖ } \rightarrow \theta / \# \mathrm{CV}_{-} \#
$$

\section{- [ð] pronounced as $\left[\mathrm{t}^{\mathrm{h}}\right]$}

The last deviation of the [ð] sound was the substitution of [ð] with $\left[\mathrm{t}^{\mathrm{h}}\right]$, as in 'loathe' $\left[\mathrm{lot}^{\mathrm{h}}\right]$. Similar to the second deviation, in the substitution of $[\delta]$ with $\left[\mathrm{t}^{\mathrm{h}}\right]$, voiced dental fricative was being replaced with voiceless alveolar stop. The difference of the second and this deviation was that $\left[\mathrm{t}^{\mathrm{h}}\right]$ is the allophone of [t]. Allophone, as being explained by Deterding and Poedjosoedarmo (1998, p. 78), is a variant of a phoneme. Since allophone is a phoneme's variation, it shares the same elements of sound production as the phoneme. It usually occurs only in certain positions within a word. The voiceless stop, $/ t$, for example, aspirated when it occurs at the beginning of a stressed syllable, as in 'talk', and unaspirated when it occurs after a syllable-initial /s/, as in 'stalk' (Deterding \& Poedjosoedarmo, 1998, p. 78). In the deviation the students made, they aspirated the [t] sound as a replacement of the letters 'th' that should be articulated as [ð]. For that reason, it is clear that they are very different from one another. Thus, when the students replaced $[ð]$ with $\left[\mathrm{t}^{\mathrm{h}}\right]$, they created a deviation. 
The deviation of [ð] into $\left[\mathrm{t}^{\mathrm{h}}\right]$ happened only in the final position of a word after a vowel, as in 'loathe' $\left[\mathrm{lot}^{\mathrm{h}}\right]$ and the linguistic environment description of the deviation is:

$$
\partial \rightarrow \mathrm{t}^{\mathrm{h}} / \# \mathrm{CV}_{-} \#
$$

If it is seen from the point of view of English phonetic system as what has been explained above, most of the deviations happened because the students deviated two or more general characteristics of the [ð] sound, except for the replacement of $[\delta]$ with $[\theta]$. However, since the subjects are generally Indonesians and especially since this particular sound does not exist in Indonesian phonetics system, it is essential to describe this deviation from the point of view of Indonesian phonetic system.

Generally, Indonesian phonetic system does not differentiate the two categories of the places of articulation, that is, dental and alveolar. Still, according to Basri (2006, p. 46), some Indonesian sounds, such as [t] and [d], are more likely to be categorized as dentals. This fact helps to explain that in the first two deviations, in which the students deviated the sound of $[ð]$ to [d] and [t], the students actually tried to find the closest sound that had the equivalent result as [ð], and since the nearest sound provided by the Indonesian phonetic system is [d] and [t], they pronounced [ð] as either [d] or $[\mathrm{t}]$.

\section{The Pronunciation of $[\theta]$}

In general, $[\theta]$ is categorized as a voiceless dental fricative. $[\theta]$ is another consonantal sound that is typically English sound; therefore, other languages, especially Indonesian, may not have this exact sound in their phonetic systems. Hence, the English department students as the subjects of this research deviated the sound to several possibilities in their attempts of articulating $[\theta]$ as seen in Table 3 .

Different from $[\mathrm{v}]$ and $[ð]$, which have smaller possibilities in the deviations, $[\theta]$ was deviated into six possible errors, from the replacement of $[\theta]$ with $[\mathrm{t}]$ to the deletion of $[\theta]$. 
Table 3. The Deviation of [ $\theta]$

\begin{tabular}{|c|c|c|c|c|c|c|}
\hline $\begin{array}{l}\text { Positi- } \\
\text { ons }\end{array}$ & Words & $\begin{array}{c}\text { Standard } \\
\text { Phonetics } \\
\text { Transcription }\end{array}$ & $\begin{array}{l}\text { Students' } \\
\text { Actual } \\
\text { Pronunci } \\
\text { ation }\end{array}$ & $\begin{array}{l}\text { Deviati- } \\
\text { ons }\end{array}$ & $\begin{array}{l}\text { Phonological } \\
\text { Environments }\end{array}$ & $\begin{array}{l}\% \text { of } \\
\text { Errors }\end{array}$ \\
\hline \multirow{6}{*}{ initial - } & Thursday & {$[\theta 3$ :rzdeI $]$} & [t3:rzdeI] & \multirow{3}{*}[\theta\rightarrow\mathrm{t}]{} & \multirow{3}{*}{$\theta \rightarrow \mathrm{t} / \# \_\mathrm{V}$} & $96 \%$ \\
\hline & thieves & [өirfz] & [tirfz] & & & $92 \%$ \\
\hline & thunder & {$[\theta \wedge$ ndər $]$} & [t^ndər $]$ & & & $88 \%$ \\
\hline & thigh & {$[\theta \mathrm{aI}]$} & [ðaI] & {$[\theta \rightarrow ð]$} & $\theta \rightarrow$ d\#_Vv\# & $12 \%$ \\
\hline & thought & {$[\theta \mathrm{Oxt}]$} & {$\left[\mathrm{t}^{\mathrm{h}} \mathrm{J} \mathrm{t} \mathrm{t}\right]$} & {$\left[\theta \rightarrow \mathrm{t}^{\mathrm{h}}\right]$} & $\theta \rightarrow \mathrm{t}^{\mathrm{h}} / \#$ _VC\# & $8 \%$ \\
\hline & theme & {$[\theta \mathrm{irm}]$} & [dirm] & {$[\theta \rightarrow d]$} & $\theta \rightarrow \mathrm{d} / \#$ _VC\# & $8 \%$ \\
\hline \multirow{7}{*}{ medial } & enthusiastic & [InOu:ziæstIk] & 3ntu:ziastIk] & \multirow{2}{*}[\theta\rightarrow\mathrm{t}]{} & $\theta \rightarrow \mathrm{t} / \# \mathrm{VC}_{-} \mathrm{V}$ & $96 \%$ \\
\hline & $\begin{array}{l}\text { anything } \\
\text { breathless }\end{array}$ & $\begin{array}{l}\text { [eniӨIy] } \\
\text { [bre } \theta \text { los] } \\
\end{array}$ & $\begin{array}{l}\text { [enitIy] } \\
\text { [bretləs] }\end{array}$ & & $\theta \rightarrow \mathrm{t} / \mathrm{V}_{-} \mathrm{VC \#}$ & $\begin{array}{l}88 \% \\
84 \% \\
\end{array}$ \\
\hline & monthly & 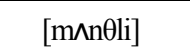 & [m^nli] & {$[\theta \rightarrow \varnothing]$} & $\theta \rightarrow \varnothing / \# \mathrm{CVC}_{-} \mathrm{CV} \#$ & $76 \%$ \\
\hline & ether & [ir $\theta ə r]$ & [3:dər] & {$[\theta \rightarrow \mathrm{d}]$} & $\theta \rightarrow \mathrm{d} / \# \mathrm{~V}_{-} \mathrm{VC} \#$ & $52 \%$ \\
\hline & lethargic & [ləӨa:rdzIk] & [lot ${ }^{\text {ha }}$ :jIk] & {$\left[\theta \rightarrow \mathrm{t}^{\mathrm{h}}\right]$} & $\theta \rightarrow \mathrm{t}^{\mathrm{h}} / \# \mathrm{CV} \_\mathrm{VC}$ & $20 \%$ \\
\hline & birthday & [b3:rrydeI] & [b3:sdeI] & {$[\theta \rightarrow \mathrm{s}]$} & $\theta \rightarrow \mathrm{s} / \# \mathrm{CVC} \_\mathrm{CVv} \#$ & $12 \%$ \\
\hline & ether & 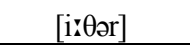 & [3:ðər] & {$[\theta \rightarrow ð]$} & $\theta \rightarrow$ $/ \# \mathrm{~V}_{-} \mathrm{VC} \#$ & $8 \%$ \\
\hline \multirow{6}{*}{ final } & wrath & {$[\mathrm{ræ} \theta]$} & [ræt] & \multirow{3}{*}[\theta\rightarrow\mathrm{t}]{} & $\theta \rightarrow \mathrm{t} / \# \mathrm{CVv} \_\#$ & $88 \%$ \\
\hline & moth & {$[\mathrm{mb} \theta]$} & [mot] & & $\theta \rightarrow \mathrm{t} / \# \mathrm{CV}_{-} \#$ & $88 \%$ \\
\hline & health & [hell] & [helt] & & $\theta \rightarrow \mathrm{t} / \mathrm{CVCC}_{-} \#$ & $84 \%$ \\
\hline & worth & [w3:r $\theta]$ & [w3:rd] & {$[\theta \rightarrow \mathrm{d}]$} & $\theta \rightarrow \mathrm{d} / \# \mathrm{CVC} \_\#$ & $12 \%$ \\
\hline & worth & [w3:r $\theta]$ & {$\left[\mathrm{w} 3 \mathrm{rrt}^{\mathrm{h}}\right]$} & \multirow[b]{2}{*}[\theta\rightarrow\mathrm{t}^{\mathrm{h}}]{} & $\theta \rightarrow \mathrm{t}^{\mathrm{h}} / \# \mathrm{CVC} \_\#$ & $4 \%$ \\
\hline & $\begin{array}{c}\text { booth } \\
\text { bath }\end{array}$ & $\begin{array}{l}{[\text { bu: } \theta]} \\
{[\text { bæ } \theta]}\end{array}$ & $\begin{array}{l}{\left[\text { burt } t^{\mathrm{h}}\right]} \\
{\left[\text { bæt }^{\mathrm{h}}\right]}\end{array}$ & & $\theta \rightarrow \mathrm{t}^{\mathrm{h}} / \# \mathrm{CV}_{-} \#$ & $\begin{array}{l}4 \% \\
4 \% \\
\end{array}$ \\
\hline
\end{tabular}

\section{- $[\theta]$ pronounced as $[t]$}

Table 3 shows clearly that $[\theta]$ was often deviated to [t] in the initial, medial and final positions. It can happen since both $[\theta]$ and $[t]$ share one thing in common, that is, both of them are voiceless sounds. Nonetheless, when the students replaced $[\theta]$ with $[t]$, they diverged two important features of $[\theta]$ : they changed the place of articulation of $[\theta]$ from dental to alveolar and in terms of the manner of articulation, they stopped the air stream for a brief of time and then released it abruptly, creating stop instead of fricative. Thus, by replacing $[\theta]$ with [t], the students made their first deviation. 
In initial position of a word, $[\theta]$ was replaced with [t] after a vowel such as in 'Thursday' [t3:rzdeI], 'thieves' [ti:fz], and 'thunder' [t/nndər] and could be described as: $\theta \rightarrow \mathrm{t} / \#$ V

In medial position, $[\theta]$ was replaced by $[t]$ if it was located between a consonant and a vowel, as in 'enthusiastic' [3nturziastik]. and between two vowels, for example, in 'anything' [enitIn] and 'breathless' [bretlos]. The phonological environments could be formulated as follows:

$$
\theta \rightarrow \mathrm{t} /\left\{\begin{array}{l}
\# \mathrm{VC}_{-} \mathrm{V} \\
\mathrm{V} \mathrm{VC}_{-}
\end{array}\right\}
$$

In final position, $[\theta]$ was replaced by $[t]$ if it was placed after a diphthong, such as in 'wrath' [ræt], after a vowel, as in the word 'moth' [mot], and after a consonant, for example, 'health' [helt]. The phonological environments could be formulated as:

$$
\theta \rightarrow \mathrm{t} /\left\{\begin{array}{c}
\# \mathrm{CVV}_{-}{ }^{\#} \\
\# \mathrm{CV}{ }_{-} \# \\
\# \mathrm{CVC}_{-} \#
\end{array}\right\}
$$

\section{- $[\theta]$ pronounced as $[d]$}

The second deviation found in the articulation of $[\theta]$ was the substitution of $[\theta]$ with $[d]$. In this case, the students obviously altered the sound production of $[\theta]$. In the first place, they deviated the sound by vibrating the vocal cords when they should not vibrate them at all. Then, they moved the place of articulation from dental to alveolar. In the end, they produced a stop when they should have produced a fricative. Consequently, the students generated the next deviation in the pronunciation of $[\theta]$ when they replaced $[\theta]$ with $[d]$.

In initial position of a word, the substitution of $[\theta]$ with [d] happened before a vowel as in 'theme' [dirm] which could be described as:

$$
\theta \rightarrow \mathrm{d} / \text { \#_VC\# }
$$

In medial position, the phonological environments could be described as:

$$
\theta \rightarrow \mathrm{d} / \# \mathrm{~V}_{-} \mathrm{VCH}
$$

which means that the replacement of $[\bar{\theta}]$ with [d] occurred in the medial position of a word between two vowels, for instance, in the word 'ether' [3rdər]. 
In final position, the deviation of $[\theta]$ to [d] only happened when $[\theta]$ was after a consonant, as in the word 'worth' [w3:rd]:

$$
\theta \rightarrow \mathrm{d} / \# \mathrm{CVC}_{-} \#
$$

\section{- $[\theta]$ pronounced as [ð]}

The third deviation happened when the students replaced [ $\theta]$ with [ð]. In mispronouncing $[\theta]$ as [ð], the students altered one important feature of the sound $[\theta]$, that is, the state of the vocal cords. Generally, the sound of $[\theta]$ is produced in the situation where the vocal cords are put at a distance when the air goes by in order to make sure that the vocal cords do not make vibration. Yet, as they attempted to articulate [ $\theta]$, they closed their vocal cords when the air passed and created vibration. As a result, the sound

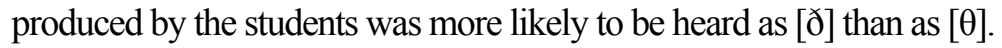

In initial position of a word, the replacement of $[\theta]$ with [ $\varnothing]$ was found if [ $\theta$ ] was placed before a diphthong, as in the word 'thigh' [ðar]. The phonological environments to describe the linguistic environment where the deviations took place was:

$$
\theta \rightarrow \text { } / \# \text { \# Vv\# }
$$

In medial position, [ð] replaced $[\theta]$ if $[\theta]$ is between two vowels, such as in 'ether' [3:ðər] and had the phonological environments as follows:

$$
\theta \rightarrow \text { ¿/\# V_VC\# }
$$

The replacement of $[\theta]$ with [ð] did not happen in the final position.

\section{- $[\theta]$ pronounced as $\left[\mathrm{t}^{\mathrm{h}}\right]$}

The fourth deviation occurred due to the fact that the students changed the sound of $[\theta]$ with $\left[\mathrm{t}^{\mathrm{h}}\right]$. This deviation was basically the same as the one of the deviations of $[ð]$, i.e. the substitution of [ð] with $\left[t^{\mathrm{h}}\right]$. Both of the deviations were similar since the students replaced the required sound, that is, [ $\theta]$ and [ð], with the allophone of [t]. On both cases, the students aspirated the $[\mathrm{t}]$ sound that they made. Still, on this particular deviation, the students did not alter all the features of [ $\theta]$. They still produced the right state of the vocal cords for the sound required, that is, voiceless. On the other hand, they also still deviated the place and manner of articulation, from dental to alveolar and from fricative to stop. Thus, by producing $\left[\mathrm{t}^{\mathrm{h}}\right]$, they deviated $[\theta]$. 
In initial position of a word, $\left[\mathrm{t}^{\mathrm{h}}\right]$ replaced $[\theta]$ before a vowel as in the word 'thought' [ $\left.\mathrm{t}^{\mathrm{h}} \mathrm{J} \mathrm{t} \mathrm{t}\right]$ which could be described as:

$$
\theta \rightarrow \mathrm{t}^{\mathrm{h}} / \# \text { _VC\# }
$$

In medial position, the changing of $[\theta]$ to $\left[\mathrm{t}^{\mathrm{h}}\right]$ happened if $[\theta]$ was between two vowels, such as in 'lethargic' [lot $\left.{ }^{\mathrm{h}} a_{\mathrm{r} j \mathrm{j}} \mathrm{l}\right]$ with the formulation of phonological environments as:

$$
\theta \rightarrow \mathrm{t}^{\mathrm{h}} / \# \mathrm{CV} \_\mathrm{VC}
$$

In the final position, the replacement of $[\theta]$ to $\left[\mathrm{t}^{\mathrm{h}}\right]$ had two possibilities: after a consonant, such as 'worth' [w3:rth $]$, and after a vowel, such as in the words 'booth' [bu:th $\left.{ }^{\mathrm{h}}\right]$ and 'bath' $\left[\mathrm{brt}^{\mathrm{h}}\right]$. The description of the phonological environments:

$$
\theta \rightarrow \mathrm{t}^{\mathrm{h}} /\left\{\begin{array}{c}
\# \mathrm{CVC}_{-} \# \\
\# \mathrm{CV}{ }_{-} \#
\end{array}\right\}
$$

\section{- $[\theta]$ pronounced as $[s]$}

Another deviation done by the students was the substitution of $[\theta]$ with [s] which could be found in the medial position only, between two consonants such as in 'birthday' [b3氵sdeI], with the description of phonological environments as follows:

$$
\theta \rightarrow \text { s/ \#CVC_CVv\# }
$$

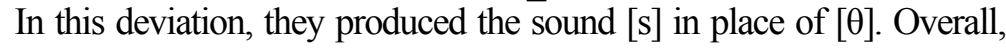
$[\mathrm{s}]$ is characterized as voiceless alveolar fricative, whereas $[\theta]$ is known as voiceless dental fricative. By contrasting the two sounds, it can be seen that in substituting the sound $[\theta]$ with $[\mathrm{s}]$, they merely diverged the place of articulation of the required sound. Instead of producing the sound in the dental position, they produced it in the alveolar position. These two positions are very dissimilar since dental is produced when somebody puts his tongue tip behind his upper front while the alveolar sounds are constructed when the front part of the tongue is placed on the alveolar ridge. For that reason, when the students replaced $[\theta]$ with $[\mathrm{s}]$, they made another deviation in the pronunciation of $[\theta]$.

\section{- [0] pronounced as [Ø]}

The final deviation of $[\theta]$ was produced when the students completely deleted this voiceless dental fricative sound in their articulation. The deletion of $[\theta]$ only happened in the medial position between two 
consonants, as in the word 'monthly' [m^nli], which could be described as having phonological environments as follows:

$$
\theta \rightarrow \varnothing / \# \mathrm{CVC}_{-} \mathrm{CV \#}
$$

From all of the six deviations above, there were only two deviations that could be truly linked back to the Indonesian phonetic system. They were the replacement of $[\theta]$ with $[t]$ and of $[\theta]$ with [d]. The main reason for that is the fact that the only sounds that are considered as dental in Indonesian are the $[t]$ and [d] sounds. Additionally, since $[\theta]$ as an English dental sound does not exist in Indonesian phonetic system, the students replaced it with the sounds they knew as having similar place of articulation as $[\theta]$. Thus, the occurrence of this deviation might be based on the same reason as the replacement of $[ð]$ with [t].

\section{The Pronunciation of $[t]]$}

Basically, $[\mathrm{t}]$ can be described through three features, that is, the state of the vocal cords, the place of articulation, and the manner of articulation. In this case, $[t]]$ is a voiceless palatal affricate sound. Similar to any other sounds investigated in this paper, $[t]]$ does not exist in Indonesian phonetic system and from Table 4, it is clear that this sound also gave difficulties to the Indonesian students since there were five deviations done by the students regarding this particular sound: the replacements of $[\mathrm{t}]$ with [c], $[\mathrm{t}]]$ with $\left[\mathrm{k}^{\mathrm{h}}\right]$, [t] $]$ with $\left.[\mathrm{h}],[\mathrm{t}]\right]$ with $[\mathrm{s}]$, and $\left.[\mathrm{t}]\right]$ with $[\mathrm{f}]$.

Although the deviations of $[\mathrm{t}] \mathrm{f}$ were considerably varied, none of them occurred in the final position. Hence, it is fair to note down that $[\mathrm{t}]]$ did not become a problematic sound as long as it turned up in the final position of a word.

\section{- [t] pronounced as [c]}

In this deviation, the students replaced voiceless palatal affricate sound with voiceless palatal stop sound. It means that in replacing the required sound with [c], they had deviated only one characteristics of [t]]. In this deviation, they deviated the manner of articulation from affricate, which is indicated by the existence of friction, to stop, which is shown by the sudden release of the blocked air stream. Subsequently, it is clear that in replacing $[t]]$ with [c], the students created a deviation. 
In initial position of a word, [t] was pronounced as [c], when [t]] was put before a vowel, for example, in the word 'chess' [ces], 'cheap' [cirp], and 'chin' [cIn]. The formulation of the circumstances surrounding the occurrence of the deviation:

$$
\mathrm{t} \rightarrow \mathrm{c} / \mathrm{H}_{-} \mathrm{VCH}
$$

In medial position of a word, $[\mathrm{t}]$ was pronounced as $[\mathrm{c}]$, when $[\mathrm{t}]]$ was placed between a consonant and a vowel, as in 'purchased' [p3rrcisd], and between two vowels, for instance, 'leaching' [lirciy] and 'watching' [warcin]. The phonological environments used to show the linguistic environment of the deviations are:

$$
\mathrm{t} f \rightarrow \mathrm{c} /\left\{\begin{array}{c}
\# \mathrm{CVC}-\mathrm{VC} \# \\
\# \mathrm{CV} \text { - VC\# }
\end{array}\right\}
$$

\begin{tabular}{|c|c|c|c|c|c|c|}
\hline $\begin{array}{l}\text { Positi- } \\
\text { ons }\end{array}$ & Words & $\begin{array}{c}\text { Standard } \\
\text { Phonetics } \\
\text { Transcription }\end{array}$ & $\begin{array}{c}\text { Students' } \\
\text { Actual } \\
\text { Pronuncia- } \\
\text { tion } \\
\end{array}$ & $\begin{array}{c}\text { Deviati- } \\
\text { ons }\end{array}$ & $\begin{array}{l}\text { Phonological } \\
\text { Environments }\end{array}$ & $\begin{array}{l}\% \text { of } \\
\text { Errors }\end{array}$ \\
\hline \multirow{3}{*}{ Initial } & chess & {$\left[\mathrm{t} \int \mathrm{es}\right]$} & [ces] & \multirow{3}{*}[\mathrm{t}f\rightarrow\mathrm{c}]{} & \multirow{3}{*}{$\mathrm{t} \int \rightarrow \mathrm{c} / \#$ \#_VC\# } & $40 \%$ \\
\hline & cheap & [t $\left.\int \mathrm{ixp}\right]$ & [cisp] & & & $4 \%$ \\
\hline & chin & {$\left[\mathrm{t} \int \mathrm{In}\right]$} & [cIn] & & & $4 \%$ \\
\hline \multirow{8}{*}{ medial } & purchased & [p3:ritfIsd] & [p3:rk' $\left.{ }^{\mathrm{h}} \mathrm{Is}\right]$ & \multirow{2}{*}[\mathrm{t}f\rightarrow\mathrm{k}^{\mathrm{h}}]{} & $\mathrm{t} f \rightarrow \mathrm{k}^{\mathrm{h}} / \# \mathrm{CVC}$ _VC\# & $20 \%$ \\
\hline & Orchard & [כ:rrt]ərd] & [כ:rk $\left.{ }^{\mathrm{h}} ə \mathrm{rd}\right]$ & & $\mathrm{t} f \rightarrow \mathrm{k}^{\mathrm{h}} / \# \mathrm{VC} \_\mathrm{VCC} \#$ & $8 \%$ \\
\hline & purchased & [p3:rtt Isd] & [p3:rcIs] & \multirow{3}{*}[\mathrm{t}f\rightarrow\mathrm{c}]{} & $\mathrm{t} f \rightarrow \mathrm{c} / \# \mathrm{CVC}$ _VC\# & $12 \%$ \\
\hline & leaching & [lixtSIy] & [lircIn] & & $\mathrm{t} f \rightarrow \mathrm{c} / \# \mathrm{CV} \quad \mathrm{VC} \#$ & $4 \%$ \\
\hline & watching & [wa:t $\left.\int \mathrm{In}\right]$ & [warcin] & & & $4 \%$ \\
\hline & purchased & [p3:rtt[Is] & [p3:rhIs] & {$[\mathrm{t} f \rightarrow \mathrm{h}]$} & $\mathrm{t} f \rightarrow \mathrm{h} / \# \mathrm{CVC}$ _VC\# & $4 \%$ \\
\hline & marching & [marrt]In] & [ma:rsIn] & $[\mathrm{t}] \rightarrow \mathrm{s}]$ & $\mathrm{t} f \rightarrow \mathrm{s} / \mathrm{HCVC} \_\mathrm{VC} \#$ & $4 \%$ \\
\hline & marching & [marrt]In] & [ma:reIn] & $\left.[\mathrm{t}] \rightarrow \int\right]$ & $\mathrm{t} f \rightarrow \int / \# \mathrm{CVC} \_\mathrm{VC} \#$ & $4 \%$ \\
\hline final & - & - & - & - & - & $0 \%$ \\
\hline
\end{tabular}

Table 4. The Deviation of [t]

\section{- [t]] pronounced as $\left[\mathrm{k}^{\mathrm{h}}\right]$}

In making this deviation, the students messed up the two features of [t]]. If observed from the three essential features (i.e. the state of the vocal cords, the place of articulation, and the manner of articulation), those two 
sounds are almost completely different. Aside from the fact that both of them are voiceless sounds, the place and manner of articulation of both sounds are dissimilar. First of all, $[\mathrm{t}]]$ has a completely different place of articulation from $[\mathrm{k}]$. The first sound is made in palatal, whereas the latter sound is produced in velar. It means that $[\mathrm{t}]]$ is produced if the front part of the tongue is raised to the hard palate, while $[\mathrm{k}]$ is produced when the back of the tongue is positioned against the velum. Then, the next feature they deviated was the manner of articulation. Essentially, $[\mathrm{t}] \mathrm{is}$ an affricate sound, still they articulated it in a very different manner, that is, stop, producing $[\mathrm{k}]$ instead of $[\mathrm{t}]$. Besides the two elements of $[\mathrm{t}]$, the students also altered the required sound by adding the aspiration to the $[\mathrm{k}]$ sound. Therefore, by replacing $[\mathrm{t}]]$ with $\left[\mathrm{k}^{\mathrm{h}}\right]$, the students made a deviation in the pronunciation of $[\mathrm{t}]$.

This deviation only happened in medial position of a word, that is, between a consonant and a vowel, such as in 'purchased' [p3.rk $\left.{ }^{\mathrm{h}} \mathrm{Is}\right]$ and 'Orchard' [ว`rk ${ }^{\text {h }}$ rd] :

$$
\mathrm{t} f \rightarrow \mathrm{k}^{\mathrm{h}} /\left\{\begin{array}{l}
\# \mathrm{CVC} \text { - VC\# } \\
\# \mathrm{VC} \text { - VCC\# }
\end{array}\right\}
$$

\section{- [t]] pronounced as [h]}

The third deviation done by the students was the substitution of [t $\mathrm{t}]$ with [h]. In articulating [t]], the students were supposed to make voiceless palatal affricate sound. Still, in their articulation, they tended to sound it as voiceless glottal fricative sound. From the contrasting of the two sound characteristics, it is clear that they altered two elements of [t $\mathrm{t}]$ : the place and the manner of articulation. In making this deviation, they firstly altered the place of articulation since they made a glottal sound, which is generally produced in a space between the vocal cords without the active use of the tongue and the other parts of the mouth, in place of the palatal sound. Then, in terms of manner of articulation, they created 'hissing noise' instead of 'friction' resulting in the production of fricative sound. For all that reason, substituting $[\mathrm{t}]]$ with $[\mathrm{h}]$ causes deviation to happen.

$[\mathrm{t}]$ was pronounced as $[\mathrm{h}]$ only in medial position of a word, after a consonant and before a vowel, such as in the word 'purchased' [p3:rhIs] that could be described as:

$$
\mathrm{t} f \rightarrow \mathrm{h} / \mathrm{\# CVC} \_\mathrm{VC} \#
$$




\section{- $[\mathrm{t}]$ pronounced as $[\mathrm{s}]$}

The fourth deviation happened when the students replaced $[t]]$ with $[\mathrm{s}]$. This deviation has many similarities with the third deviation (i.e. the substitution of [t] with [h]). In the first place, in both deviations, the students deviated two elements of $[\mathrm{t}]$ ], that is, the place and manner of articulation. Then, in terms of manner of articulation, the two sounds, [s] and [h], are placed in the same category, that is, fricative. It means that in both deviations, they replaced affricate sound with fricative sound. The difference lays only on the fact that $[\mathrm{s}]$ is an alveolar sound and $[\mathrm{h}]$ is a glottal sound. Overall, it can be stated that by replacing $[\mathrm{t}\}]$ with $[\mathrm{s}]$, they made another deviation of $[t]$ since the voiced palatal fricative sound is different from voiceless alveolar fricative sound.

This deviation only happened in medial position of a word, when $[\mathrm{t}]]$ was put between a consonant and a vowel as in 'marching' [marrsig]:

$$
\text { t } \rightarrow \mathrm{s} / \# \mathrm{CVC} \_\mathrm{VC} \#
$$

\section{- [t]] pronounced as [j]}

The last deviation occurred when the students deviated the $[t]$ sound to []]. From all the deviations made by the students, this deviation was the only deviation that can be considered as minor. The reason for it comes from the fact that in this deviation, they simply altered the manner of articulation from the affricate sound to the fricative sound. Nonetheless, that single difference is the only one feature that differentiates $[\mathrm{t}]]$ from $[j]$. Hence, once the students substituted [t]] with [j], they made another deviation.

The deviation occurred only in medial position of a word, when $[\mathrm{t}]]$ was put between a consonant and a vowel as in [marrfIn]:

$$
\text { t } \int \rightarrow \int / \# \mathrm{CVC}_{\text {_ }} \mathrm{VC \#}
$$

Having described each of the deviations from the English phonetic system standpoint, it is also important to explain the deviations based on the Indonesian phonetic system. From all five deviations found in the articulation of $[\mathrm{t}]$, the first deviation (i.e. the replacement of $[\mathrm{t}]]$ with $[\mathrm{c}]$ ) was the only deviation that was entirely influenced by the Indonesian sound. It might happen because [c] is essentially an Indonesian sound. Additionally, [c] does not even exist in English phonetic system. When observing the deviations, it could be noticed that possibly all the deviations above occurred due to the fact that $[\mathrm{t}]$ does not exist in Indonesian phonetic 
system and that in order to make the sound easier to be pronounced, the students tried to replace it with the sounds they were familiar with.

\section{The Pronunciation of [d]]}

The next distinct English sound that cannot be found in Indonesian phonetic system is [d3]. Overall, in order to make this particular sound appropriate, a person should pay attention to its specific sound production. Based on the state of the vocal cords, [d3] is categorized as a voiced sound; it is a palatal sound based on its place of articulation; and an affricate sound based on the manner of articulation. Table 5 shows that there are eight kinds of deviations occurred in the pronunciation of the voiced palatal affricate sound [d]].

Table 5. The Deviation of [d3]

\begin{tabular}{|c|c|c|c|c|c|c|}
\hline $\begin{array}{c}\text { Positi } \\
\text { ons }\end{array}$ & Words & $\begin{array}{c}\text { Standard } \\
\text { Phonetics } \\
\text { Transcription }\end{array}$ & $\begin{array}{c}\text { Students' } \\
\text { Actual } \\
\text { Pronuncia- } \\
\text { tion } \\
\end{array}$ & $\begin{array}{c}\text { Deviati- } \\
\text { ons }\end{array}$ & $\begin{array}{l}\text { Phonological } \\
\text { Environments }\end{array}$ & $\begin{array}{l}\text { \% of } \\
\text { Errors }\end{array}$ \\
\hline \multirow{4}{*}{ initial } & ginger & [dzIndzər] & [gIngər] & \multirow{4}{*}[\mathrm{d}3\rightarrow\mathrm{g}]{} & \multirow{2}{*}{$\mathrm{d} 3 \rightarrow \mathrm{g} / \mathrm{H}_{-} \mathrm{VC}$} & $32 \%$ \\
\hline & general & [dzenrəl] & [g3nəral] & & & $4 \%$ \\
\hline & geography & [dziragrefi] & [gi:ojrəfi] & & $\mathrm{d} 3 \rightarrow \mathrm{g} / \# \_\mathrm{Vv}$ & $4 \%$ \\
\hline & ginger & [dzIndzər] & [jInjər] & & $\mathrm{d} 3 \rightarrow \mathrm{j} / \#$ _VC & $4 \%$ \\
\hline \multirow{7}{*}{ medial } & cordial & [kJ:rdzəl] & [kJ:rdial] & \multirow{3}{*}{\multicolumn{2}{|c|}{$\begin{aligned} {[\mathrm{d} z \rightarrow \mathrm{d}] \mathrm{d} 3 \rightarrow \mathrm{d} / \# \mathrm{CVC} \text { _VC\# } } \\
\mathrm{d} 3 \rightarrow \mathrm{d} / \mathrm{CV} \text { _VC\# } \\
\mathrm{d} 3 \rightarrow \mathrm{g} / \# \mathrm{CVC} \_\mathrm{VC} \#\end{aligned}$}} & $96 \%$ \\
\hline & individual & [IndIvIdzuəl] & [IndIvIdual] & & & $76 \%$ \\
\hline & ginger & [dzIndzər] & [gIngər] & & & $32 \%$ \\
\hline & agile & [ædzəl] & [ægil] & \multirow[t]{2}{*}[\mathrm{d}3\rightarrow\mathrm{g}]{} & d3 $\rightarrow$ g/\#V_VC\# & $32 \%$ \\
\hline & legions & [lixdzənz] & [lI:gənz] & & $\mathrm{d} 3 \rightarrow \mathrm{g} / \#$ CV_VCC\# & $20 \%$ \\
\hline & ginger & [dzIndzər] & [jInjər] & \multirow{2}{*}[\mathrm{d}3\rightarrow\mathrm{j}]{} & $\mathrm{d} 3 \rightarrow \mathrm{j} / \# \mathrm{CVC}$ _VC $\#$ & $8 \%$ \\
\hline & Trojan & [troudzən] & [trojan] & & $\mathrm{d} 3 \rightarrow \mathrm{j} / \# \mathrm{CCV}$ _VC\# & $8 \%$ \\
\hline \multirow{10}{*}{ final } & bridge & [brId3] & [britf] & \multirow{3}{*}[\mathrm{d}3\rightarrow\mathrm{t}f]{} & $\mathrm{d} 3 \rightarrow \mathrm{g} / \# \mathrm{CCV}$ \# & $84 \%$ \\
\hline & page & [peId3] & [peIt $]$ & & $\mathrm{d} 3 \rightarrow \mathrm{g} / \# \mathrm{CV} \mathrm{v}_{-} \#$ & $84 \%$ \\
\hline & marriage & [mærId3] & [mærrt $]$ & & d3 $\rightarrow$ g/CV_\# & $84 \%$ \\
\hline & gouge & [gavd3] & [gouk] & {$[\mathrm{d} 3 \rightarrow \mathrm{k}]$} & $\mathrm{d} 3 \rightarrow \mathrm{k} / \# \mathrm{CV}_{-} \#$ & $20 \%$ \\
\hline & gouge & [gaudz] & [goug] & {$[\mathrm{d} z \rightarrow \mathrm{g}]$} & $\mathrm{d} 3 \rightarrow \mathrm{g} / \# \mathrm{CV} \mathrm{v}_{-} \#$ & $8 \%$ \\
\hline & gouge & [gavd3] & [goul] & {$\left[\mathrm{d} 3 \rightarrow \int\right]$} & $\mathrm{d}_{3} \rightarrow \int / \# \mathrm{CV}_{\mathrm{v}} \#$ & $8 \%$ \\
\hline & gouge & [gavdz] & [goUs] & {$[\mathrm{d} 3 \rightarrow \mathrm{s}]$} & $\mathrm{d} 3 \rightarrow \mathrm{s} / \# \mathrm{CV}_{-} \#$ & $4 \%$ \\
\hline & gouge & [gavdz] & [goUf] & {$[\mathrm{d} 3 \rightarrow \mathrm{f}]$} & $\mathrm{d} 3 \rightarrow \mathrm{f} / \# \mathrm{CV}_{-} \mathrm{v}_{-}$ & $4 \%$ \\
\hline & gouge & [gavdz] & [gouj] & {$[\mathrm{d} 3 \rightarrow \mathrm{j}]$} & $\mathrm{d} 3 \rightarrow \mathrm{j} / \# \mathrm{CV}_{-} \#$ & $4 \%$ \\
\hline & gouge & [gavdz] & [goud] & {$[\mathrm{d} 3 \rightarrow \mathrm{d}]$} & $\mathrm{d} 3 \rightarrow \mathrm{d} / \# \mathrm{CV} v_{-} \#$ & $4 \%$ \\
\hline
\end{tabular}




\section{- [d] pronounced as [g]}

The first deviation in the pronunciation of [d3] was the replacement of [d3] with [g]. In this deviation, the students replaced voiced palatal affricate with voiced velar stop. In essence, these two sounds have the same state of vocal cords: voiced, meaning that the vocal cords are vibrated in the production of both sounds. Nevertheless, [d] and [g] are very different in terms of place and manner of articulation. For one thing, to produce a palatal sound, the front part of the tongue has to be raised to the hard palate, while velar is produced when the back of the tongue is positioned against the velum. Then, concerning the manner of articulation, affricate is produced if the air stream is completely stopped briefly and then the articulators are released slightly in order to generate friction, whereas stop is made if the air stream is completely stopped in the oral cavity for a brief period, and then released abruptly. Therefore, since [dz] and [g] are completely distinctive sounds, it is clear that the students made a deviation.

In initial position of a word, [d3] was pronounced as [g] before a vowel as in 'ginger' [gIngər] and 'general' [g3nəral], also in the initial position before a diphthong as in the pronunciation of 'geography' [girojrefi] with the phonological environments as:

$$
\mathrm{d} 3 \rightarrow \mathrm{g} /\left\{\begin{array}{l}
\# \_\mathrm{VC} \\
\# \_\mathrm{Vv}
\end{array}\right\}
$$

In medial position, [d3] was pronounced as [g] when it was between a consonant and a vowel, for instance, 'ginger' [gIngrr] and between two vowels as in the words 'agile' [ægil] and 'legions' [lırgənz] which could be described as:

$$
\mathrm{d} 3 \rightarrow \mathrm{g} /\left\{\begin{array}{c}
\# C V C \_V C \# \\
\# V_{-} \text {VC\# } \\
\# C V_{-} \text {VCC\# }
\end{array}\right\}
$$

In final position of a word, [dz] was pronounced as [g] when it was put after diphthong such as in 'gouge' [goug] which could be formulated using the following phonological environments:

$$
\mathrm{d} 3 \rightarrow \mathrm{g} / \# \mathrm{CV}_{-} \#
$$




\section{- [d3] pronounced as [j]}

The second deviation was the replacement of [d3] with [j]. Different from the first deviation (i.e. the replacement of [d3] with [g]) in which the students deviated two main elements of [d3], in this deviation, they only deviated one element of the sound [d3]. As a matter of fact, the sounds of [d3] and [j] can be considered as the same sounds, especially if the two sounds are being observed from the state of the vocal cords and the place of articulation. Those two sounds are voiced sounds, which mean that they are produced with the vibration of the vocal cords. Then, [d3] and [j] are produced if the front part of the tongue is raised to the hard palate, which indicates that those two sounds are categorized as palatals. Nonetheless, those two sounds are differentiated by noticing their manners of articulation. Viewed from this specific constriction of the sound production, these two sounds are completely different from each other since [d3] is an affricate and [j] is a stop. Thus, the deviation was generated when the students replaced the sound [d3] with [j].

In initial position of a word, [d3] was pronounced as [j] when it is put before a vowel, such as in the word 'ginger' [jInjor] which could be described as:

$$
\mathrm{d} 3 \rightarrow \mathrm{j} / \# \_\mathrm{VC}
$$

In medial position, [d3] was pronounced as [j] when it was put between a consonant and a vowel, for example, 'ginger' [jinjər] and between vowels as in the pronunciation of 'trojan' [trojan] so that it could be described as:

$$
\mathrm{d} 3 \rightarrow \mathrm{j} /\left\{\begin{array}{l}
\# \mathrm{CVC} \_\mathrm{VC} \# \\
\# \mathrm{CCV} \_\mathrm{VC} \#
\end{array}\right\}
$$

In final position, [d3] was pronounced as [j] when it was put after a diphthong such as 'gouge' [gouj] and can be formulated using the following phonological environments:

$$
\mathrm{d} 3 \rightarrow \mathrm{j} / \# \mathrm{CV}_{-} \#
$$

\section{- [d] pronounced as [d]}

The next deviation was the replacement of [d]] with [d], as in 'cordial' [kJ:rdial] and 'individual' [IndIvIdual]. This particular deviation is somehow similar to the first deviation (i.e. the replacement of [d3] with 
[g]). First of all, [dz] and [d] have the same state of vocal cords, that is, voiced. Secondly, in this replacement of [d3], the place and manner of articulations of the two sounds are diverse. Regarding the place of articulation, [d]] is a palatal, which is generated if the speaker raises the front part of his tongue to the hard palate, while [d] is an alveolar, which should be produced by placing the front part of the tongue on the alveolar ridge. Meanwhile, based on the manner of articulation, [d3] is made with the existence of the friction, which is the characteristic of the affricate sound, and [d] is produced by briefly stopping the air stream and therefore known as stop. Consequently, by replacing [d]] with [d], the students made a deviation.

This deviation only happened in the medial and final positions of a word. In the medial position, [d] was being replaced by [d] if [d] was between a consonant and a vowel as in 'cordial' [kJirdial], and between two vowels, for example: 'individual' [IndIvIdual]. Thus, it could be described as:

$$
\mathrm{d} 3 \rightarrow \mathrm{d} /\left\{\begin{array}{c}
\# \mathrm{CVC}-\mathrm{VC} \# \\
\mathrm{CV} \_\mathrm{VC} \#
\end{array}\right\}
$$

In final position, the deviation happened when [d3] followed a diphthong such as in 'gouge' [goud] and described as:

$$
\mathrm{d} 3 \rightarrow \mathrm{d} / \# \mathrm{CVv}_{-} \#
$$

\section{- [d]l pronounced as [t]]}

Another deviation was the substitution of [dz] with [t]]. This deviation shows that the students replaced the voiced palatal affricate sound with the voiceless palatal affricate sound. From the contrasting of the two sounds' characteristics, it is clear that in this phonological error, the students generated the deviation due to the fact that they altered the state of the vocal cords of the required sound. Instead of producing a vibration in their articulation, they eliminated that vibration causing the voiceless sound to be heard. For that reason, it can be concluded that they made another deviation when they replaced $[\mathrm{d} 3]$ with $[\mathrm{t}]$.

This deviation only happened in the final position of a word which can be formulated using the following phonological environments: 


$$
\mathrm{d} 3 \rightarrow \mathrm{t} \int /\left\{\begin{array}{c}
\# \mathrm{CCV}_{-} \# \\
\mathrm{CV}_{-} \# \\
\# \mathrm{CV}_{-} \#
\end{array}\right\}
$$

The patterns state that [d3] was pronounced as [t]] if [d] was located in the final position of a word after a vowel as in 'bridge' [britf] and 'marriage' [mærIt]] and after a diphthong, such as in the word 'page' [peItf].

\section{- [d3] pronounced as [k]}

The substitution of the sound [d3] with [k] occurred as the fifth deviation. The deviation happened because of the replacement of the voiced palatal affricate sound with the voiceless velar stop sound. Unlike any previous deviations above, in this deviation, the students did not only deviate one or two elements of the expected sound, but they altered all the features that characterized [d3]. On the subject of the state of the vocal cords, the students made a voiceless sound instead of a voiced sound. Moreover, in relation to the place of articulation, [d3] is made in velar in place of palatal generating the sound $[\mathrm{k}]$. Finally, concerning the manner, the students were more likely to completely block the air stream for a brief period of time and then release it abruptly rather than to release the articulators slightly. Thus, since $[\mathrm{d} 3]$ and $[\mathrm{k}]$ have different characteristics, when the students replaced [d3] with [k], unconsciously they made a deviation.

The deviation of [d3] into [k] happened only when [d3] was put in the final position of a word after a diphthong, as in the pronunciation of the word 'gouge'[gouk]). It can be formulated using the following phonological environments:

$$
\mathrm{d} 3 \rightarrow \mathrm{k} / \# \mathrm{CVv}_{-} \#
$$

\section{- [d]] pronounced as [ []}

In this noteworthy deviation, [d3] was being replaced by []]. Once again, the deviation happened because the students altered two elements of [d3]. It means that although the students managed to generate the sound in 
the correct place of articulation, they still deviated the state of the vocal cords and the manner of articulation. If observed from the place of articulation, [d3] and []] are both palatals. However, if viewed from the state of the vocal cords, [d3] is a voiced sound while []] is a voiceless sound. Additionally, in terms of manner of articulation, [d3] is an affricate and [ [] is a fricative. Hence, in the view of the state of the vocal cords and the manner of articulation, [d3] and []] should not be regarded as the same sound.

The deviation of [d]] into []] only happened in the final position of a word after a diphthong, as in the pronunciation of the word 'gouge' [gov]]. It can be formulated using the following phonological environments:

$$
\mathrm{d} 3 \rightarrow \int / \# \mathrm{CV}_{\text {_ }} \#
$$

\section{- [d] pronounced as [s]}

The replacement of [d3] with [s] was the seventh deviation found in the pronunciation of [d3]. This deviation is similar to the fifth deviation since in the fifth and seventh deviations, the students messed up all the important aspects of [d3]. In this deviation, the students replaced the voiced palatal affricate with the voiceless alveolar fricative. From this contrasting, it is clear that the students altered the state of the vocal cords, the place of articulation and the manner of the articulation. Hence, in making the deviation, it can be said that firstly, they deviated [d]] from the supposed voiced sound where they had to vibrate their vocal cords to eliminate the vibration. Then, they constructed [s] by placing their front part of the tongue on their alveolar ridge rather than generating [d3] in the palatal. Lastly, instead of producing friction, they generated the 'hissing noise'. Subsequently, [d] is in fact different from [s].

The deviation of [d3] into [s] only happened in the final position of a word after a diphthong, as in the pronunciation of the word 'gouge' [gous] which can be formulated using the following phonological environments:

$$
\text { d3 } \rightarrow \text { s/ \#CVv_\# }
$$

\section{- [d]l pronounced as [f]}

The last deviation found was the substitution of voiced palatal the state of the vocal cords, place and manner of articulations. For one thing, [d3] as 
a voiced consonant should be produced with a vibration of the vocal cords, but the students did not generate the vibration in their articulation and thus creating a voiceless consonant [f]. Furthermore, in the place of articulation, they did not raise the front part of the tongue to the hard palate; instead they met their lower lip with their upper teeth together, producing a labiodental sound. In the end, concerning the manner of articulation, they tended to generate the 'hissing noise' rather than friction. Consequently, the replacement of [d]] with [f] showed that the students produced deviation in their pronunciation.

The deviation of [d] into [f] occurred merely in the final position of a word, as in the pronunciation of the word 'gouge' [gouf]. It can be formulated using the following phonological environments:

$$
\mathrm{d} 3 \rightarrow \mathrm{f} / \# \mathrm{CV}_{\mathrm{B}} \#
$$

Since this paper investigated the errors the students made in producing the English consonantal sounds that do not exist in Indonesian phonetic system, it is essential to discuss the deviations from the perspective of Indonesian phonetic system. Basically, if viewed from the contrast between English and Indonesian consonants, it can be said that the replacement of [d3] with [j] was the only deviation occurred mainly due to the influence of the mother tongue, particularly since [j] can be found only in Indonesian phonetic system. That assumption can be taken because when the students were faced with the sounds that do not exist in their mother tongue, they tried to find the closest sound that had the similar outcome as the required sound. In the case of the pronunciation of [d3], it seems that [j] as a voiced palatal stop has the closest similar effect as [d3], which is a voiced palatal affricate.

\section{The Pronunciation of [3]}

The last English consonantal sound that was problematic for the subjects as English department students was [3]. In general, English phonetic system illustrates [3] as a voiced palatal fricative. Regardless of the conventional description of [3], this particular sound becomes a problem for the learners since it does not exist in Indonesian phonetic system. In table 6, it can be seen that in articulating this distinct English sound, students tended to deviate it. If compared to other sounds observed in this paper, the kinds of deviations made by the students in the 
pronunciation of [3] were the most varied of all. On the whole, there were ten deviations made by the students in articulating [3]: the replacement of [3] with [d], [z], [s], [j], [t]], [j], [d]], [g], [k], and [Ø].

\section{- [3] pronounced as [d]}

The replacement of [3] with [d] was the first deviation done by the students in the pronunciation of [3]. In this deviation, they replaced the sound of voiced palatal fricative with the sound of voiced alveolar stop. By contrasting of the characteristics of the two sounds, it is clear that in making the deviation, they students altered the two features of [3].

Table 6. The Deviation of [3]

\begin{tabular}{|c|c|c|c|c|c|c|}
\hline $\begin{array}{l}\text { Positi- } \\
\text { ons }\end{array}$ & Words & $\begin{array}{c}\text { Standard } \\
\text { Phonetics } \\
\text { Transcription }\end{array}$ & $\begin{array}{c}\text { Students' } \\
\text { Actual } \\
\text { Pronunciati- } \\
\text { on } \\
\end{array}$ & $\begin{array}{l}\text { Deviati- } \\
\text { ons }\end{array}$ & Pattern Possibilities & $\begin{array}{l}\text { \% of } \\
\text { Errors }\end{array}$ \\
\hline \multirow{13}{*}{ initial } & Zsa-Zsa & [3aza] & [zaza] & \multirow{3}{*}[3\rightarrowz]{} & \multirow{3}{*}{$3 \rightarrow \mathrm{z} / \#_{-} \mathrm{V}$} & $72 \%$ \\
\hline & Zha & [3a] & [za] & & & $48 \%$ \\
\hline & Zhi & [3i] & [zi] & & & $48 \%$ \\
\hline & genre & [3a:nre] & [dz3:nre] & {$[3 \rightarrow d 3]$} & $3 \rightarrow \mathrm{d} 3 / \#_{2} \mathrm{VC}$ & $64 \%$ \\
\hline & Zha & [3a] & $[\mathrm{t}] \mathrm{a}]$ & \multirow{3}{*}[3\rightarrowt]{} & \multirow{3}{*}{$3 \rightarrow \mathrm{t} / \mathrm{H}_{-} \mathrm{V} \#$} & $44 \%$ \\
\hline & Zhi & [3i] & {$[\mathrm{t}$ ji $]$} & & & $44 \%$ \\
\hline & Zho & [30] & {$\left[t f_{0}\right]$} & & & $44 \%$ \\
\hline & Zsa-Zsa & [3aza] & [ $\left[\mathrm{a} \int \mathrm{a}\right]$ & \multirow{3}{*}[3\rightarrow\int]{} & \multirow{3}{*}{$3 \rightarrow \int / \#_{-} V$} & $16 \%$ \\
\hline & Zha & [3a] & {$[\mathrm{a}]$} & & & $8 \%$ \\
\hline & Zhi & [3i] & {$[[\mathrm{i}]$} & & & $8 \%$ \\
\hline & Zsa-Zsa & [3aza] & [sasa] & {$[3 \rightarrow s]$} & $3 \rightarrow \mathrm{s} / \#_{-} \mathrm{V}$ & $8 \%$ \\
\hline & genre & [3a:nre] & [g3:nr3] & {$[3 \rightarrow g]$} & $3 \rightarrow \mathrm{g} / \#_{-} \mathrm{VC}$ & $8 \%$ \\
\hline & genre & [3a:nro] & [j3:nr3] & {$[3 \rightarrow \mathrm{j}]$} & $3 \rightarrow \mathrm{j} / \#$ _VC & $4 \%$ \\
\hline \multirow{6}{*}{ medial } & decision & [dIsI3n] & {$[\mathrm{dIsI}[\mathrm{n}]$} & \multirow{3}{*}[3\rightarrow\int]{} & $3 \rightarrow \int / \# \mathrm{CVCV}_{-} \mathrm{C} \#$ & $96 \%$ \\
\hline & occasion & [əkeI3ən] & [okeI〔ən] & & \multirow{2}{*}{$3 \rightarrow \int / V_{1} V_{C H}$} & $92 \%$ \\
\hline & explosion & [Iksplouzən] & [Iksplo]ən] & & & $92 \%$ \\
\hline & unusual & [^nju:3əl] & [^njuisuəl] & \multirow{3}{*}[3\rightarrows]{} & \multirow{3}{*}{$3 \rightarrow \mathrm{s} / \mathrm{V}_{-} \mathrm{V}$} & $44 \%$ \\
\hline & measure & [mezər] & [mesər] & & & $4 \%$ \\
\hline & treasure & [trezər] & [tresər] & & & $4 \%$ \\
\hline
\end{tabular}

English Department, Faculty of Letters, Petra Christian University http://www.petra.ac.id/ puslit/journals/dir.php?DepartmentID=ING 


\begin{tabular}{|c|c|c|c|c|c|c|}
\hline $\begin{array}{l}\text { Positi- } \\
\text { ons }\end{array}$ & Words & $\begin{array}{c}\text { Standard } \\
\text { Phonetics } \\
\text { Transcription }\end{array}$ & $\begin{array}{c}\text { Students' } \\
\text { Actual } \\
\text { Pronunciati- } \\
\text { on } \\
\end{array}$ & $\begin{array}{c}\text { Deviati- } \\
\text { ons }\end{array}$ & Pattern Possibilities & $\begin{array}{c}\text { \% of } \\
\text { Errors }\end{array}$ \\
\hline \multirow{9}{*}{ final } & beige & [beI3] & [beId3] & \multirow{3}{*}[3\rightarrow\mathrm{d}3]{} & $3 \rightarrow \mathrm{d} 3 / \# \mathrm{CVv} \#$ & $28 \%$ \\
\hline & garage & [grra:3] & [gara:dz] & & \multirow{2}{*}{$3 \rightarrow \mathrm{d} 3 / \mathrm{CV}_{-} \#$} & $28 \%$ \\
\hline & mirage & [mIra:3] & [mIra:dz] & & & $28 \%$ \\
\hline & rouge & [ru:3] & {$[\mathrm{r} \wedge \mathrm{k}]$} & {$[3 \rightarrow \mathrm{k}]$} & $3 \rightarrow \mathrm{k} / \# \mathrm{CV}_{-} \#$ & $16 \%$ \\
\hline & beige & [beI3] & [beIg] & \multirow{2}{*}[3\rightarrowg]{} & $3 \rightarrow \mathrm{g} / \# \mathrm{CVv}_{-} \#$ & $8 \%$ \\
\hline & rouge & [ru:3] & [ru:g] & & $3 \rightarrow \mathrm{g} / \# \mathrm{CV} \_\#$ & $8 \%$ \\
\hline & prestige & [presti:3] & [prestixs] & {$[3 \rightarrow s]$} & $3 \rightarrow \mathrm{s} / \mathrm{CV} \_\#$ & $8 \%$ \\
\hline & prestige & [presti:3] & [prestixd] & {$[3 \rightarrow d]$} & $3 \rightarrow \mathrm{d} / \mathrm{CV}_{-} \#$ & $4 \%$ \\
\hline & rouge & [ru:3] & {$[\mathrm{ru}:]$} & {$[3 \rightarrow \varnothing]$} & $3 \rightarrow \varnothing / \# C V_{-} \#$ & $4 \%$ \\
\hline
\end{tabular}

First of all, they deviated the place of articulation by placing the front part of their tongue on the alveolar ridge when they were actually supposed to raise the front part of their tongue to the hard palate. Then, on the subject of the manner of articulation, although they managed to stop the air stream completely for a brief period of time, they mistakenly released the air abruptly rather than blocking the air steam partially and then pushing it through the narrow opening. Thus, by replacing [3] with [d], they generated a deviation.

This deviation only occurred in final position of a word after a vowel as in the pronunciation of the word, 'prestige', [prestiss] with the description of the phonological environments of the deviation as:

$$
3 \rightarrow \mathrm{d} / \mathrm{CV}_{-} \#
$$

\section{- [3] pronounced as [z]}

The second deviation was the replacement of [3] with [z]. In this replacement of voiced palatal fricative with voiced alveolar fricative, the students altered only one feature of [3]. Similar to the previous deviation (i.e. the replacement of [3] with [d]), the students in making this deviation also replaced the place of articulation from palatal to alveolar. It means that they placed the front part of their tongue on the alveolar ridge rather than raised it to the hard palate. Hence, it is clear that by producing $[z]$ instead of [3], they deviated the sound [3]. 
The replacement of [3] with [z] only occurred in initial position of a word, before a vowel such as in the words 'Zsa-Zsa' [zaza], 'Zha' [za] and 'Zhi' [zi] with the description of the phonological environments of the deviation as:

$$
3 \rightarrow \mathrm{z} / \#_{-} \mathrm{V}
$$

\section{- [3] pronounced as [s]}

Another deviation was the replacement of voiced palatal fricative [3] with voiceless alveolar fricative [s]. In this deviation, the students once again altered two features of the sound [3], that is, the state of the vocal cords and the place of articulations. For one thing, in producing this deviation they did not vibrate their vocal cords as what is required in the sound production of [3]. Then, in terms of place of articulation, they yet again replaced palatal sound with alveolar sound. Thus, by replacing [3] with [s], the students made completely different sounds and as a result, they created another deviation.

In initial position of a word, [3] was replaced with [s] when it occurred before a vowel as in the word 'Zsa-zsa' [sasa], having the description of the phonological environments of the deviation as:

$$
3 \rightarrow \mathrm{s} / \#_{-} \mathrm{V}
$$

In medial position of a word, [3] was replaced with [s] when it occurred between two vowels, for example, in the words 'unusual' [^nju:sual], 'measure' [mesər], and 'treasure' [tresər] which could be described as:

$$
3 \rightarrow \mathrm{s} / \mathrm{V}_{-} \mathrm{V}
$$

In final position of a word, [3] was replaced with [s] when it was put after a vowel such as in the word, 'prestige' [prestiss] with the description of the phonological environments of the deviation as:

$$
3 \rightarrow \mathrm{s} / \mathrm{CV}_{-} \#
$$

\section{- [3] pronounced as [j]}

The fourth deviation was the substitution of [3] with [j] which that the sound of voiced palatal fricative was being replaced with the sound of voiced palatal stop. Considering the number of errors in the elements of the sound production, this deviation can be stated to have the least error in its 
sound production. It is because in this deviation, the students altered solely one feature of [3], that is, the manner of articulation. On the subject of the manner of articulation, they replaced the fricative sound with the stop sound, which means that they made an abrupt release of the air stream after stopping it completely when they theoretically should produce a 'hissing noise'. Then, when dealing with the movement of the air, they made a sudden release of the blocked air stream instead of released the articulators slightly to produce friction. Therefore, by producing a voiced palatal stop [j] instead of voiceless palatal affricate [3], the students made another deviation of [3].

This deviation only happened in the initial position of a word before a vowel as in 'genre' [g3:nr3] or [j3:nr3]. It has the phonological environments of deviation as:

$$
3 \rightarrow \mathrm{j} / \#+\mathrm{VC}
$$

\section{- [3] pronounced as [t]]}

The replacement of [3] with [t] was the other deviation made by the students in the pronunciation of [3]. This deviation can be seen from the example of 'Zha' [ $\mathrm{t} \mathrm{a}$ ] or 'Zhi' [ $\mathrm{t} \mathrm{j}]$. In this case, the students partially messed up the features of [3] since [3] is a voiced palatal fricative while [t] is a voiceless palatal affricate. It means that in producing this deviation, the students did not vibrate their vocal cords even when they were required to vibrate them, and they made a friction when they should produce 'hissing noise'. For those reasons above, when the students articulated [ $t]$ ] instead of [3], they produced a deviation.

This deviation only happened in initial position of a word before a vowel such as in the words 'zha' [ $[\mathrm{f} a]$, 'zhi' [t $\mathrm{fi}]$ and 'zho' [t $\mathrm{f}_{\mathrm{o}}$, having the description as:

$$
3 \rightarrow \mathrm{t} / \mathrm{\#} \text { - V\# }
$$

\section{- [3] pronounced as []]}

The sixth deviation done by the students was the substitution of [3] with []]. If it is seen from the general characteristics of the two sounds, [3] and [j] can almost be categorized as similar sounds for the reason that they were two distinct sounds if being observed from the state of the vocal 
cords. Whereas [3] is a voiced sound, []] is a voiceless sound. Consequently, when the students changed [3] to []], they in fact had generated a deviation in their pronunciation. This deviation only occurred in the initial and medial positions of a word.

In initial position of a word, it occurred before a vowel as in the words 'Zsa-Zsa' [ [a]a], 'Zha' [ $\mathrm{Ja}$ ] and 'Zhi' [ [i] and have the description of phonological environments as:

$$
3 \rightarrow \int / \#_{-} \mathrm{V}
$$

In the medial position of a word, [3] was replaced with []] when it occurred between a vowel and a consonant, as in 'decision' [dIsI $[\mathrm{n}]$ and between a diphthong and a vowel, such as in the words 'occasion'

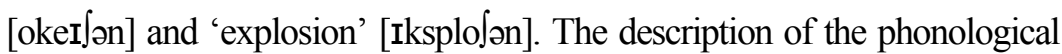
environments of deviation is:

$$
3 \rightarrow \int /\left\{\begin{array}{c}
\# \mathrm{CVCV} \_\mathrm{C} \# \\
\mathrm{Vv} \mathrm{VC}_{-}
\end{array}\right\}
$$

\section{- [3] pronounced as [d]}

The replacement of voiced palatal fricative [3] with voiced palatal affricate [d3] was another deviation found in the students' pronunciation. This deviation can actually be considered as a minor deviation since the students merely deviated one feature of [3], that is, the manner of articulation. In this deviation, they briefly stopped the air stream completely and then released the articulators slightly so that friction is produced rather than partially blocked the air steam while it is pushed through the narrow opening. Thus, by producing [d3] instead of [3], the students had produced another deviation. This deviation did not happen in the medial position of a word.

In initial position of word, [3] was replaced with [d3] when it occurred before a vowel as in the word 'genre' [d33:nre] with the description of the phonological environments of deviation as:

$$
3 \rightarrow \mathrm{d} 3 / \#+V C
$$

In final position of a word, [3] was replaced with [d3] when it occurred after a diphthong as in 'beige' [beId3] or after a vowel as in 'garage'

English Department, Faculty of Letters, Petra Christian University http://www.petra.ac.id/ puslit/journals/dir.php?DepartmentID=ING 
[gara:d3] and 'mirage' [mIra:d3]. The phonological environments of deviation could be described as:

\section{- [3] pronounced as [g]}

$$
3 \rightarrow \mathrm{d} 3 /\left\{\begin{array}{c}
\# \mathrm{CV} \mathrm{C}_{-} \\
\mathrm{CV} \_\#
\end{array}\right\}
$$

The eighth deviation was the replacement of [3] with [g]: [3] is generally voiced palatal fricative, whereas $[\mathrm{g}]$ is essentially voiced velar stop. Initially the students managed to produce the sound in the correct state of articulation in which they vibrated their vocal cords. However, in terms of place and manner of articulation, they produced deviation since they raised the front part of their tongue to the hard palate instead of raising the front part of the tongue to the hard palate, and also for the reason that they stopped the air stream completely before releasing it abruptly when they actually should create 'hissing noise'. Accordingly, it is apparent that the students generated deviation when replacing [3] with [g]. This deviation did not happen in the medial position of a word.

In initial position of a word, [3] was replaced with [g] when it occurred before a vowel such as in the word 'genre' [g3:nr3], with the description of the phonological environments of deviation as:

$$
3 \rightarrow \mathrm{g} / \text { \#_ }_{\mathrm{VC}}
$$

In final position of a word, [3] was replaced with [g] when it occurred after a diphthong as in 'beige' [beIg], after a vowel as in 'rouge' [ru:g]. The phonological environments of deviation could be described as:

$$
3 \rightarrow \mathrm{g} /\left\{\begin{array}{l}
\# \mathrm{CV} v_{-} \\
\# \mathrm{CV} \_\#
\end{array}\right\}
$$

\section{- [3] pronounced as [k]}

The substitution of voiced palatal fricative [3] with voiceless velar stop [k] was another deviation in the pronunciation of [3]. This substitution of [3] with [k] shows that students altered all three features of [3] (i.e. the state of the vocal cords, the place and manner of articulation). The deviation was made since they did not vibrate their vocal cords, positioned the back of their tongue against the velum, and stopped the movement of the air stream 
completely before releasing it abruptly. Subsequently, it can be stated that the replacement of [3] with [k] was another deviation made by the students.

This deviation only happened in the final position of a word after a vowel, for instance, in the word 'rouge' [r/k], with the description as:

$$
3 \rightarrow \mathrm{k} / \# \mathrm{CV} \text { _ \# }
$$

\section{- [3] is pronounced as [Ø]}

The last deviation found was the deletion of [3]. In this particular deviation, the students removed the sound of voiceless palatal affricate from their pronunciation completely. It happened only in the final position of a word after the vowel such as in the pronunciation of the word 'rouge' [ru:]. The phonological environments of the deviation could be described as:

$$
3 \rightarrow \varnothing / \# \mathrm{CV}_{-} \#
$$

Having described each of the deviations of the sound [3], it is also necessary to refer the deviations to the Indonesian phonetic system since the students' mother tongue is Indonesian and the consonantal sound observed here, [3], does not exist in Indonesian phonetic system. Having stated that, the single deviation that can be linked back to the Indonesian phonetic system in this part was the replacement of [3] with [j], especially since the replacing sound, [j], does not exist in English phonetic system but can be found in Indonesian sound system. Generally, Indonesian sound system categorizes the sound [j] as voiced palatal stop. It means that to produce this particular sound, a speaker should vibrate his vocal cords, raise the front part of his tongue to the hard palate, and block the air stream briefly before releasing it abruptly. Hence, if this deviation is observed from the state of the vocal cords and the manner of articulation, the reason of the replacement may not be pulled out logically due to the fact that the two sounds do not share the same state of vocal cords or manner of articulation. However, if it is seen from the place of the articulation, it is apparent that the sound of [3] and [j] could share the same category, since [3] in English phonetic system and [j] in Indonesian phonetic system were categorized as palatal. Therefore, it could be concluded that since English learners whose native language is Indonesian are not familiar with the sound [3], they might try to find the closest possible sound that they knew and replaced [3] with it. In this case, the potential sound for the replacement is [j]. 


\section{CONCLUSION}

From the findings and analysis, it was found out that first, the students made phonological errors in all of the pronunciation of the six English consonantal sounds being observed in this study. Additionally, the phonological errors could be found in all three positions of occurrences, with the exception for $[\mathrm{t}]$ in the final position, since none of the students observed made any error of this particular sound in that specific position. Yet, it should also be noticed that although they made those phonological errors, they still managed to pronounce some of the words correctly every now and then. Secondly, the students made thirty-four kinds of deviations in all. The thirty-four kinds of deviations included the replacement of [v] with [f], the replacements of [ð] with [d], [t], $[\theta]$ and $\left[t^{\mathrm{h}}\right]$, the replacement of $[\theta]$ with $[\mathrm{t}],[\mathrm{d}],\left[\mathrm{t}^{\mathrm{h}}\right],[ð]$ and $[\mathrm{s}]$ and the deletion of $[\theta]$, the substitution of $[\mathrm{t}]$ with [c], [h], [s], [d] and [k $\left.\mathrm{k}^{\mathrm{h}}\right]$, the replacement of [d3] with [g], [j], [d], $[\mathrm{t}]],[\mathrm{j}],[\mathrm{k}],[\mathrm{s}]$ and $[\mathrm{f}]$, and the replacement of [3] with [d], [z], [s], [j], [t]], []], [d]], [g] and [k] and the deletion of [3]. Then, it could also be figured out that one particular English sound, namely the sound of voiceless palatal affricate, [3], created many difficulties for the students if compared to the other five English consonantal sounds observed.

This research is hopefully useful for both English learners and teachers, whose mother tongue is Indonesian. For one thing, by knowing that English department students tend to make the phonological errors in the pronunciation of the six observed English consonantal sounds, both English learners and teachers are expected to pay more attention to the articulation of those particular sounds. Moreover, they are also expected to become more aware that those six sounds are distinctive English sounds and should not be replaced by Indonesian sounds whatsoever. At the same time, it is hoped that by having this paper, the English teachers may be constantly reminded that these English sounds tend to generate problems on the students' pronunciation, and therefore, they can develop the pronunciation lessons by concentrating on those problematic sounds.

\section{REFERENCES}

Bowman, M. (2002). A contrastive analysis of English and Tahi and its practical applications for teaching English pronunciation. English Teacher Journal, $4(1), 40-52$.

Clarey, M. E., \& Dixson, R. J. (1963). Pronunciation exercises in English. New York: Regents Publishing Company.

English Department, Faculty of Letters, Petra Christian University http://www.petra.ac.id/ puslit/journals/dir.php?DepartmentID=ING 
Deterding, D. H., \& Poedjosoedarmo, G. R. (1998). The sound of English: Phonetics and phonology for English teachers in Southeast Asia. Singapore: Prentice Hall.

English pronunciation/listening. (n.d.). eslp025units01,02,05,06,07,11. Retrieved September 22, 2006, from Okanagan College, British Columbia, English As A Second Language (ESL) Web site: http://international.ouc.bc.ca/ pronunciation/eslp025unit01.pdf.

Fasold, R. W., \& Connor-Linton, J. (Eds.). (2006). An introduction to language and linguistics. Cambridge: Cambridge University Press.

O’Grady, W., Dobrovolsky, M., \& Katamba, F. (1996). Contemporary linguistics: An introduction. Essex: Pearson Education.

Lanteigne, B. (2006). Common, persistent errors in English by Brazilian Portugese speakers. TEFL Web Journal, 4(1). Retrieved August 21, 2006, from http://www.teflweb-j.org/v4n1/Brazilians.pd.

Moeliono, A. M., \& Dardjowidjojo, S. (2003). Tata bahasa baku bahasa Indonesia $\left(3^{\text {rd }}\right.$ ed.). [Indonesian grammar $\left(3^{\text {rd }}\right.$ ed. $)$ ]. Jakarta: Balai Pustaka.

Odden, D. (2006). Introducing phonology. Cambridge: Cambridge University Press.

Prator, C., \& Robinett, B. (1972). Manual of American English pronunciation (3 ${ }^{\text {rd }}$ ed.). New York: Holt, Reinehart and Winston.

Richards, J., Platt, J., \& Weber, H., (1992). Longman dictionary of applied linguistics. Essex: Longman.

Taylor, L. (1993). Pronunciation in action. New York: Prentice Hall International.

Vernick, J., \& Nesgoda, J. (1980). American English sounds and spellings for beginning ESL students. Pittsburgh: University of Pittsburgh Press. 